Discussion Paper No. 14-062

\title{
Determinants of the Duration of European Appellate Court Proceedings in Cartel Cases
}

Florian Smuda, Patrice Bougette, and Kai Hüschelrath

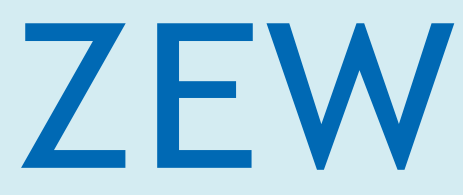

Zentrum für Europäische Wirtschaftsforschung $\mathrm{GmbH}$ Centre for European Economic Research 
Discussion Paper No. 14-062

\title{
Determinants of the Duration of European Appellate Court Proceedings in Cartel Cases
}

\author{
Florian Smuda, Patrice Bougette, \\ and Kai Hüschelrath
}

Download this ZEW Discussion Paper from our ftp server:

http://ftp.zew.de/pub/zew-docs/dp/dp14062.pdf

Die Discussion Papers dienen einer möglichst schnellen Verbreitung von neueren Forschungsarbeiten des ZEW. Die Beiträge liegen in alleiniger Verantwortung der Autoren und stellen nicht notwendigerweise die Meinung des ZEW dar.

Discussion Papers are intended to make results of ZEW research promptly available to other economists in order to encourage discussion and suggestions for revisions. The authors are solely responsible for the contents which do not necessarily represent the opinion of the ZEW. 


\title{
DETERMINANTS OF THE DURATION OF EUROPEAN APPELLATE COURT PROCEEDINGS IN CARTEL CASES
}

\author{
Florian Smuda\#, Patrice Bougette* and Kai Hüschelrath*
}

September 2014

\begin{abstract}
The duration of appellate court proceedings is an important determinant of the efficiency of a court system. We use data of 234 firm groups that participated in 63 cartels convicted by the European Commission between 2000 and 2012 to investigate the determinants of the duration of the subsequent one- or two-stage appeals process. We find that while the speed of the firststage appellate court decision depends on the court's appeals-related workload, the complexity of the case, the degree of cooperation by the firms involved and the clarity of the applied rules and regulations, the second-stage appellate court proceedings appear to be largely unaffected by those drivers. We take our empirical results to derive conclusions for both firms that plan to file an appeal as well as public policy makers.
\end{abstract}

Keywords Law and economics, antitrust policy, cartels, appeals, European Union

JEL Class K21, K41, K42, L41

\# Researcher, Competition and Regulation Research Group, ZEW Centre for European Economic Research and MaCCI Mannheim Centre for Competition and Innovation, P.O. Box 1034 43, D-68034 Mannheim, Germany, E-mail: smuda@zew.de.

* Associate Professor, University of Nice Sophia Antipolis, GREDEG Law, Economics and Management Research Group, CNRS UMR 7321, 250 rue Albert Einstein, 06560 Valbonne, France, E-mail: patrice.bougette@gredeg.cnrs.fr; Research Associate, LAMETA CNRS UMR 5474, University Montpellier 1.

* Head, Competition and Regulation Research Group, ZEW Centre for European Economic Research, P.O. Box 1034 43, D-68034 Mannheim, Germany, E-mail: hueschelrath@zew.de; Coordinator, MaCCI Mannheim Centre for Competition and Innovation; Professor, University of Mannheim, L7, 3-5, D-68131 Mannheim, Germany. Corresponding author. We are indebted to Cung Truong Hoang for excellent research assistance. The usual disclaimer applies. Part of this research was conducted while Hüschelrath was visiting professor at the University of Nice Sophia Antipolis. He thanks the university and the GREDEG research centre for hospitality and support. 


\section{Introduction}

The enforcement of anti-cartel laws has become a major activity of many competition authorities around the world. For example, since the 1990s, the European Commission (EC) has implemented (and revised) a leniency program, ${ }^{1}$ completed a major reform of the fine guidelines, ${ }^{2}$ promoted the private enforcement of anti-cartel laws ${ }^{3}$ and intensified cooperation between competition authorities in the fight against particularly international cartels. ${ }^{4}$

Although the efforts of the Commission are clearly reflected in an increase in the number of convicted cartels - showing a rise from 10 cases in the 1995 to 1999 period, to 30 cases in the 2000 to 2004 period and to 33 cases in the 2005 to 2009 period - the much more dramatic change refers to the increase in fines imposed. According to the statistics published by the European Commission itself, ${ }^{5}$ the sum of fines imposed (adjusted for court judgments) shows an increase from $€ 0.271$ billion in the 1995 to 1999 period to $€ 3.2$ billion in the 2000 to 2004 period and to $€ 8.2$ billion in the 2005 to 2009 period. In relation to the number of firm groups $^{6}$ fined, these numbers correspond to an increase in the average fine per firm group from $€ 6.02$ million in the 1995 to 1999 period, to $€ 20.11$ million in 2000 to 2004 and to $€$ 39.91 million in the most recent five-year period from 2005 to 2009.

Given the substantial increase in especially the average fine per firm group, it appears likely that firms detected and convicted for cartelization by the EC are under increased pressure by both share- and stakeholders. As a consequence, they are likely to have rising incentives to override a (possibly erroneous or disproportionate) EC decision by filing an appeal with the General Court of the European Union as first-stage appellate court or subsequently with the European Court of Justice as the second-stage and highest appellate court in the European Union. Interestingly, comparing the recent numbers of first-stage appeals in European cartel cases show a significant increase from 95 appeals in the 2000 to 2004 period to 181 appeals in the 2005 to 2009 period; or in relative terms: while only about

1 A leniency program generally offers law infringers (i.e., natural persons or firms) either a fine reduction of even full amnesty from fines if they disclose an infringement to the responsible authority and (fully) cooperate with it in the subsequent investigation. For anti-cartel law infringements, the EC introduced a (corporate) leniency program in 1996 followed by a substantial revision in 2002. Four years later, in 2006, the current form of the so-called leniency notice was released after a public consultation.

2 See Guidelines on the method of setting fines imposed pursuant to Article 23(2)(a) of Regulation No 1/2003, Official Journal of the European Union, C 210, 1 September 2006, pp. 2-5.

3 See, e.g., EC press release, Commission proposes legislation to facilitate damage claims by victims of antitrust violations, 11 June 2013.

4 A substantial part of such international cooperation is organized via the International Competition Network (ICN). See also the Commission Notice on Cooperation within the Network of Competition Authorities, Official Journal of the European Union, C 101, 27 April 2004.

5 Data source: European Commission (2014), Cartel Statistics (situation as of 2 April 2014), available at http://ec.europa.eu/competition/cartels/statistics/statistics.pdf (last accessed on 20 May 2014).

6 Firms within one group are linked through ownership and are jointly liable for cartel fines. 
57 percent of all convicted firm groups decided to appeal against an EC decision in the 2000 to 2004 period, the corresponding value increased to about 86 percent in the 2005 to 2009 period suggesting a substantially increased relevance of the appeals process in European cartel cases.

Assuming that the duration of appellate court proceedings is an important determinant of the efficiency of a court system, we use data of 234 firm groups that participated in 63 cartels convicted by the European Commission between 2000 and 2012 to investigate the determinants of the duration of the subsequent one- or two-stage appeals process. We find that while the speed of the first-stage appellate court decision depends on the court's appealsrelated workload, the complexity of the case, the degree of cooperation by the firms involved and the clarity of applied rules and regulations, the second-stage appellate court proceedings appear to be largely unaffected by those drivers. We take our empirical results to derive conclusions for both firms that plan to file an appeal as well as public policy makers.

The remainder of the article is structured as follows. The following second section provides a brief characterization of the appeals process in general and the appeals process in European cartel cases in particular. Subsequently, the third section develops key hypotheses on the determinants of the duration of the appeals process in cartel cases by differentiating between five sets of explanatory variables: authority-related, court-related, appeals-related, fine-related and group-related. In the fourth section, we present our empirical analysis. While Section 4.1 characterizes our empirical model, the subsequent Section 4.2 describes the construction of the data set and presents the corresponding descriptive statistics. Section 4.3 then follows with a presentation and discussion of our estimation results before Section 4.4 closes the fourth section with the derivation of several implications for both firms that plan to file an appeal as well as public policy makers. The fifth section concludes the article by summarizing its main results and providing several avenues for future research.

\section{The appeals process and its implementation in European cartel cases}

In this section, we provide a brief characterization of the appeals process as such complemented by a discussion on the importance of its duration for both firms and public policy makers. Subsequently, we introduce the appeals process applied in EU competition law in general and EC cartel cases in particular. 


\subsection{The appeals process}

It is reasonable to assume that any decision by a court (or public authority) is made under uncertainty with both sides presenting their best cases and the court finally rendering a decision in favor of one side or the other. According to Miceli ((2009), p. 259), the best the court will be able to do is '... to assess a probability that each side's version of the facts is true'. In rendering a decision, the court is typically also committed to interpret existing laws and regulations as these are often - by construction - not deterministic but leave (at least) some discretion to the court.

The appeals process offers the losing party the possibility to seek reconsideration of their arguments - possibly leading to a diverging decision by an appellate court. ${ }^{7}$ Without denying its important constitutional role or possibly even status as a human right (see, e.g., Nobles and Schiff (2002)), we will assume in the following that the implementation of an appeals process is motivated by two main goals. First, appeals help to refine existing laws and regulations; not only by assessments of experienced appellate courts enriching existing case law (and guiding lower courts in future decisions) but also by providing signals to lawmakers on the efficiency of existing laws and regulations (see, e.g., Cooter and Ulen (2000)). If, for example, the application of a certain law or regulation is frequently followed by an unusually large amount of appeals, a publication of guidelines or even a review of the respective provision is suggested to increase procedural efficiency.

Second, the implementation of an appeals process aims at reducing the occurrence of legal errors. According to Shavell (1995), the appeals process can be viewed as a tool to correct errors because, first, parties are more likely to file an appeal if the first decision was erroneous (i.e., the act of initiating a (costly) appeal provides additional information on the (increased) likelihood of an erroneous decision). Second, the existence of an appeals process provides incentives to lower court judges to avoid erroneous decisions in the first place; basically because they become aware that errors may be uncovered by the higher court as part of an

7 From a law perspective, it is important to differentiate between the appeals process and the judicial review process (see, e.g., Schweitzer (2013) for a discussion of the latter with respect to EU competition law). Technically, the appeals process focuses on decisions by lower courts who are reassessed by higher courts on the merits of the decision under appeal while the judicial review process concentrates on assessments of decisions by a public authority (e.g., the European Commission or a national competition authority) by one or two court levels who will focus on the legality of the decision under review only. While important from a legal perspective, the economic implications of a differentiation between both processes must be considered as rather minor thereby justifying our approach to simply use the term 'appeals process' in the remainder of this article. In this respect, it is interesting to add that appeals mechanisms are also used in much wider contexts such as religious bodies, commercial trade organizations or professional sports leagues (see Shavell (1995), p. 380) thereby increasing the relevance of our empirical analysis further. 
appeal thereby damaging their reputation and career prospects (see, e.g., Shavell (2006), Levy (2005) or Chopard et al. (2014)).

Given these key motivations for the implementation of an appeals process, its actual design offers various degrees of freedom. In addition to rather general questions such as, first, who should have the right to initiate an appeal (e.g., the litigants themselves and/or the appellate court) and, second, in what time period after the initial court decision may an appeal be initiated, more specific questions include, third, whether the respective appellate court is committed to accept the case for investigation (an appeal 'as of right') or whether it can reject it (as part of a 'discretionary review'; see Cooter and Ulen (2000), p. 418); fourth, whether it has to make an entirely new judgment on the case ('de novo appeals') or is restricted to a review of the old decision based on either 'facts and law' or 'law only' as part of the appeals process; or, fifth, whether the decision of the first-stage appellate court is final or could be challenged by a second-stage appellate court (the so-called 'finality decision')?

Although it is above the scope of this article to provide a full review of answers given by various - largely theoretical ${ }^{8}$ - research articles (see generally Shavell $(1995,2010)$ or more specifically Daughety and Reinganum (2000)), it appears straightforward that an answer to the question of an optimal design of an appeals process depends on a detailed assessment of the (incremental) costs and benefits of various alternative designs. ${ }^{9}$ In this respect, for example, Shavell (1995) argues that - due to convex costs of avoiding legal errors - it is socially preferable to have a two-stage (less accurate) appeals process rather than a one-stage (more accurate) process. Furthermore, in an older contribution, Martineau (1984) questions the assumption that appeals always follow welfare-enhancing motivations and signal an increased likelihood of an erroneous decision. He argues that appeals may also be initiated for frivolous reasons; i.e., parties file (and/or delay) appeals for tactical reasons and not because

8 The existing empirical literature on the appeals process appears to be small and fragmented. While a very limited number of studies focus on assessments of the determinants of filing an appeal (see, e.g., Santolino (2010)), several other studies aim at answering the question why plaintiffs lose appeals (see, e.g., Clermont and Eisenberg (2001) and Eisenberg and Farber (2013)). For European competition policy, Günster et al. (2010) provide an empirical analysis of all European Court of Appeal Rulings of horizontal, vertical, abuse of dominance, licensing as well as joint ventures cases between 1957 and 2004. They find, inter alia, that the number of pleas positively (negatively) influences the probability of receiving partial (complete) annulment and that cases with a high number of judges are more likely to result in a complete annulment. In addition, they show that the probability of filing an appeal is significantly influenced by the length of the Commission decision, the number of accepted complaints, the number of judges and whether the case is grouped into one case or not. In a related paper, Carree et al. (2010) empirically investigate determinants of appealing EC decisions on case and firm level using a similar dataset. They identify the level of fine, the decision length and the number of parties to which the decision is addressed as significant drivers of the decision to file an appeal.

9 In the words of Shavell (1995, p. 386) it is socially desirable to invest further in the accuracy of the appeals process until ' $\ldots$... the increase in costs is outweighed by the increase in the expected gain, that is, the increase in the probability of reversal of error multiplied by the social harm from error". 
they believe that the decision is actually erroneous. ${ }^{10}$ Due to the substantial societal costs that are created by such forms of abusive behavior - such as, e.g., delays in decision making at the appellate court level - he suggests to impose sanctions on frivolous appeals in order to '.. protect both litigants and the ability of the federal appellate courts to decide cases in an expeditious and fair manner' (Martineau (1984), p. 845).

\subsection{The appeals process and its duration}

Although it is apparent that the optimal duration of an appeals process depends on its detailed aims and implemented structures, it still adds value to discuss the general importance of the duration of an appeals process for both firms that plan to file an appeal as well as public policy makers. ${ }^{11}$ From a firm's perspective, the duration of the appeals process determines the respective costs associated to it. Ceteris paribus, the longer the appeals process the more expensive it becomes in terms of both in-house human resources spent as well as salaries for external lawyers. Furthermore, the longer the appeals process, the greater the uncertainty the firm has to cope with, e.g., with respect to the correctness of the decision in general or the size of the fine in particular. Ceteris paribus, such an increased uncertainty may, e.g., result in the delay or even the termination of planned investment projects that likely would have increased social welfare (e.g., through increased innovation activities).

Turning from firms to (social welfare-maximizing) policy makers, their key aim is to assure an optimal duration (and scope) of the appeals process. On the one hand, if any appeals decision would take a prohibitively long time span, say twenty years, firms would refrain from appealing due to, e.g., the substantial amount of labor costs accrued and - as a consequence - the constitutional order would be at risk as firms are taken the factual possibility to defend themselves against (possibly arbitrary) decisions by public authorities or courts. Furthermore, as soon as fine payments are involved, the longer the respective investigation period, the longer tax payers have to wait to profit from the collected fine payments. Last but not least, longer investigation periods delay possible private enforcement activities thereby weakening the deterrent effect of antitrust laws generally.

On the other hand, however, guaranteeing a very short duration of the appeals process would either demand substantial investments in additional court capacities (thereby boosting

10 See Ormosi (2012) for a discussion of the strategic use of appeals in the context of merger control.

11 We are not aware of any (detailed) theoretical or empirical paper that focuses either on the duration of the appeals process in general or its determinants in particular. Hüschelrath et al. (2013) assess determinants of the duration of investigations by a public authority (i.e., the European Commission) in European cartel cases. However, as the majority of key characteristics of these decisions are identical for all cartel firm groups (within a certain cartel), the respective analysis had to be conducted on the broad cartel level (rather than the more detailed cartel group level as done in our empirical analysis below). 
enforcement costs) or would increase the likelihood of erroneous decisions (harming the deterrent effect of competition laws). Furthermore, a very short appeals process may increase the incentives of firms to file frivolous appeals (to make use of the still positive probability that the appellate court may (accidentally) improve the decision from their perspective).

Although it is beyond the scope of this article to balance these different cost- and benefitrelated influences in a theoretical model to arrive at an optimal duration of an appeals process, our empirical assessment of the actual drivers of its duration below is likely to provide useful insights for public policy makers in the fine-tuning of the appeals process. In particular, by identifying key drivers of the duration of the appeals process in the past, policy makers can build on these empirical results if they come to the (political) decision that the duration of the appeals process must be either increased or decreased to reach the desired welfare-optimal solution.

\subsection{The appeals process in European cartel cases}

Given the various alternative structures of an appeals process sketched in the previous sections, it becomes apparent that a meaningful empirical analysis has to be based on a detailed characterization of the specific appeals process under investigation. Under EU competition law in general and for EC cartel cases in particular, the appellate court proceedings can be either one- or two-stage. At the first stage, a cartel member that believes to have serious concerns with a (fining) decision of the EC can file an appeal with the General Court (GC) of the European Union. ${ }^{12}$ The GC - previously known as the Court of First Instance (CFI) - is composed of at least one judge from each member state. According to Article 254 of the Treaty on the Functioning of the European Union (TFEU), judges are appointed 'by common accord of the governments of the member states' for a renewable term of six years. The GC sits in chambers of usually three or five judges. Substantively, four main categories of argument can broadly be distinguished in an appeal against an EC cartel decision: fine levels, procedural aspects, facts/standard of proof aspects, and substantive assessment issues. ${ }^{13}$ In any case, the first-stage appeal must be initiated within two months of the earlier; either the publication of the Commission's decision or the notification of the firm group (Art. 263 TFEU).

12 See the consolidated version of the Rules of Procedure of the General Court, Official Journal of the European Union, 2010/C 177/02.

13 According to Camesasca et al. (2013), appeals against cartel decisions often aim at obtaining a fine reduction rather than an annulment of the fine (basically because it is rather unlikely that a firm was wrongly convicted for its participation in a cartel by the EC). 
Generally, the GC not only has the power to annul, reduce or increase the fines imposed by the EC; it also has full jurisdiction to review the entire Commission decision (including a repetition of the full assessment process). In practice, however, the GC usually focuses on an assessment of the factors linked to the correct application of the respective law provisions such as cartel duration, the gravity of the infringement or the application of the leniency program (see Geradin and Henry (2005) or Harding and Gibbs (2005)). Typically, the GC does not aim at replacing the Commission's assessment of evidence with its own.

At the second stage of the appeals process in EC cartel cases, judgments of the GC can be appealed before the European Court of Justice (ECJ) by the unsuccessful party, i.e., either the convicted firm, the EC itself or both. The ECJ is the highest European appellate court and also has the power to annul, reduce or increase the fines imposed by the GC. However, in its proceedings, it limits itself to questions of law and has no jurisdiction to (re-)review the facts and analyze the evidence that the GC used to support its findings and decision.

Before we turn to a discussion of the determinants of the duration of the appeals process in European cartel cases, we briefly would like to complement our general description of the appeals process in European cartel cases with actual data. For this purpose, Figure 1 shows both the number of convicted firms groups ${ }^{14}$ and the number of appeals ${ }^{15}$ from 2000 to 2012 .

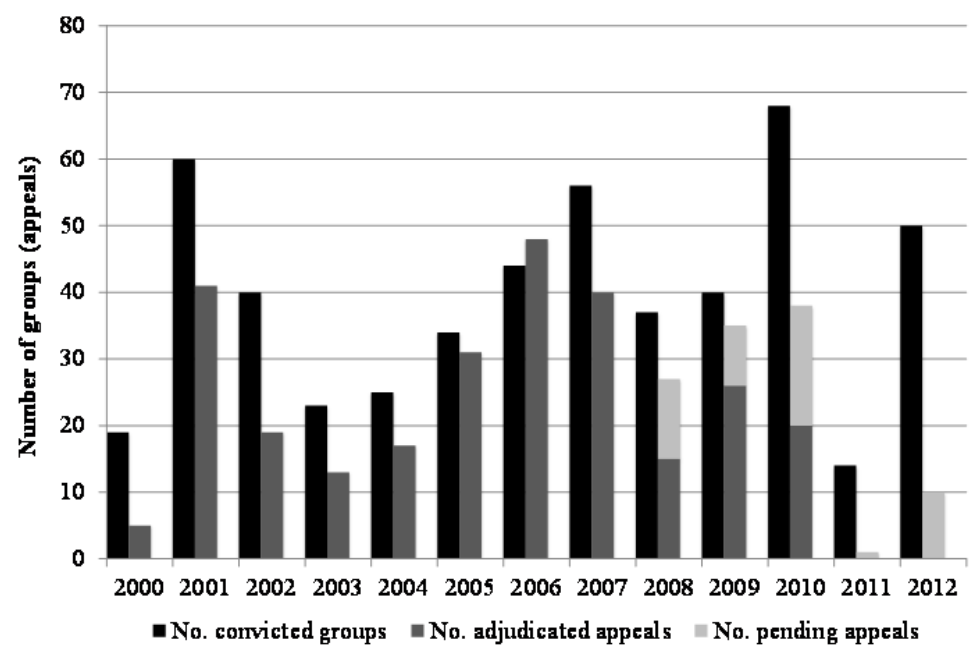

Figure 1: Number of convicted cartel groups and number of first- and second-stage appeals (adjudicated and pending), 2000-2012

14 Groups of firms were formed according to the respective EC decisions, i.e., firms within a group are linked through ownership and are jointly liable for cartel fines. As a consequence, in most years, there are more cartel groups who decided to file an appeal than convicted cartels.

15 Please note that the 'number of appeals' values (in Figures 1 and 2 only) correspond to the year in which the original EC decision on the cartel was made, i.e., a case decided by the EC in 2001 and finally ruled by the GC/ECJ in 2004 is counted in Figure 1 as appeal in the year 2001. 
As shown in Figure 1, the number of convicted cartel groups experienced a substantial increase from 2003 to 2007, followed by a rather erratic development in the years after. The number of appeals largely follows the developments of the number of convicted groups, however, the respective percentages of convicted groups to adjudicated appeals fluctuates from 26 percent in 2000 to 109 percent in 2006. In sum, from a total of 523 convicted groups, 325 decided to appeal the decision of the EC at the GC (about 62 percent).

Complementary to a general quantitative characterization of the appeals process in European cartel cases, it is important to provide some additional information on the relevance of second-stage appeals. In this respect, Figure 2 displays the share of first-stage appeals that enter the second-stage appellate court.

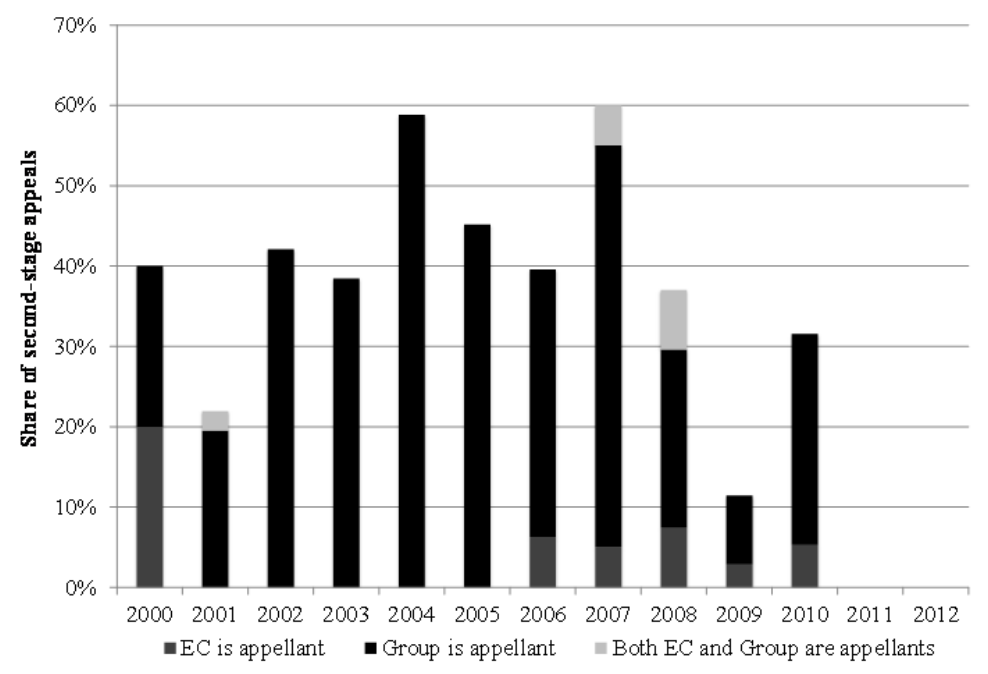

Figure 2: Share of first-stage appeals that enter the second-stage appellate court, 2000-2012

As shown in Figure 2, the share of first-stage appeals that enter the second-stage appellate court fluctuates from 12 percent in 2009 to 60 percent in 2007. Interestingly, the large majority of second-stage appeals are filed by the firms (not the EC). In sum, from a total of 325 convicted groups that decided to file a first-stage appeal, 117 (36 percent) ended up in the second-stage (either by their own decision or due to an appeal by the EC).

Although not shown in the two figures, it is interesting to add that the success rates, i.e., either a fine annulment or fine reduction for the convicted firms, diverge substantially between the two stages. While in sum 109 of the 325 first-stage appeals were successful (about 34 percent), the respective numbers drop substantially for second-stage appeals with only 6 successful out of 117 second-stage appeals leading to a success rate of about 5 percent. 


\section{Determinants of the duration of the appeals process in European cartel cases}

In this section, we develop hypotheses on possible determinants of the duration of the appeals process in European cartel cases. We differentiate between five sets of explanatory variables: authority-related, court-related, appeals-related, fine-related and group-related.

\section{Authority-related determinants}

A first set of variables relate to characteristics of the case while handled by the European Commission. First, as the GC - the first-stage appellate court - has to review the case, it appears straightforward to assume a correlation between the duration of the investigation by the EC and the subsequent investigation by the GC (as a detailed assessment of a complex case is likely to cause a longer investigation length on both stages). Second, a related explanatory variable focuses on the time span between the cartel breakdown and the start of the investigation by the EC. Here, it is straightforward to assume that the longer the respective time span, the more difficult it becomes for both the EC and the GC to gather and/or interpret the respective proof on both the existence and the scope of the cartel agreement thereby increasing the duration of the investigation. Third, the speed of the investigation also depends on the clearness of the respective rules and regulations both the EC and the appellate courts are committed to apply. In this respect, it can be assumed that the publication of guidelines such as the 2006 EC Guidelines on the Method of Setting Fines have not only improved the transparency of the decisions but consequently also had a negative impact on the average duration of the investigations.

\section{Court-related determinants}

A second group of variables relates to characteristics of the courts committed to handle the respective appeal. Although it appears obvious that the performance of the court (measured in the accuracy and quickness of its decisions) depends on multiple factors such as its organizational structure or the education standard (and practical experience) of its employees, it is - due to data constraints - rather difficult to explicitly include such possible drivers into an empirical investigation. However, a potentially key court-related driver of the duration of the investigation is rather easy to include: the number of cases that have to be handled by the court over a certain time period. For example, if there are only three appeals cases to be handled in one year, it can be expected that the GC/ECJ is (on average) able to close those cases quicker than in an otherwise comparable year with ten cases. In other words, the current 
workload of the GC/ECJ appears to be an important determinant of the duration of the investigations.

\section{Appeals-related determinants}

A third group of explanatory variables of appeals duration refers to the appeal as such. In this respect, it is, first, straightforward to assume that the overall duration of the appeals process depends on the fact whether the appeal is only filed with the first-stage appellate court (i.e., the GC) or whether the case is taken to the second and final stage and being assessed by the ECJ. Ceteris paribus, it can be expected that the overall duration increases if a second-stage investigation takes place. Furthermore, if such a second stage is entered, the duration of investigation might also depend on the party that decided to appeal the first-stage appellate court decision: either the EC and/or the respective firm(s). Second, the duration of the appeals process might depend on the number of pleas put forward as, ceteris paribus, it takes more time to investigate the relevance and correctness of four different qualitative arguments compared to just one argument. Third, it can also be expected that the length of the investigation increases as soon as firms demand an annulment of the fine rather than simply a fine reduction. Ceteris paribus, it can be assumed that the more drastic step of a fine annulment takes more time to investigate with the necessary accuracy than a comparably simple fine reduction.

\section{Fine-related determinants}

A fourth group of variables relates to characteristics of the fine issued by the EC. First, the existence and application of a leniency program (that basically offers fine reductions in exchange for full cooperation with the EC) can be expected to reduce the duration of the appeals process because the EC has more detailed information on the case and is therefore able to close it sooner. We therefore expect the investigation duration to decrease with the level of leniency discount granted to a group, i.e., the level of cooperation of a group with the EC. Second, according to the EC Guidelines on the Method of Setting Fines from 2006, the Commission is entitled to either increase or decrease the basic amount of the fine as soon as either aggravating or mitigating circumstances ${ }^{16}$ are present. As not only the presence of such factors but especially the size of the (positive or negative) discounts granted by the EC are

16 Aggravating circumstances considered by the EC are, e.g., repeat offences, refusal to cooperate with the EC or the role of leader in an infringement. Mitigating circumstances, however, include, e.g., the provision of evidence that the infringement was terminated as soon as the EC intervened or proof that the anti-competitive conduct has been authorized or encouraged by public authorities or by legislation. 
likely to be subject to some degree of discretion, it appears likely that the respective decision making extends the duration of the appeals process significantly.

\section{Group-related determinants}

A fifth and last group of variables refers to certain characteristics of the groups of firms who participated in the cartel. In this respect, we hypothesize that, first, the number of countries represented in one group may have an impact on the duration of the appeals process basically because the larger the number of countries the more difficult it becomes for the GC to receive the respective information necessary to decide on a certain case. Second, we also assume, for comparable reasons, that the number of firms within one group may have an impact on the duration of the appeals process. Ceteris paribus, it appears easier for a court to investigate an appeal submitted by a group consisting of two firms rather than to investigate a similar appeal with five firms in a group.

\section{Empirical analysis}

In this section, we present our empirical analysis to study the determinants of the duration of the appeals process for European cartel cases. While Section 4.1 characterizes our empirical model, the subsequent Section 4.2 describes the construction of the data set and presents the corresponding descriptive statistics. Section 4.3 then follows with a presentation and discussion of our estimation results before Section 4.4 closes the fourth section with the derivation of several implications for both firms that plan to file an appeal as well as public policy makers.

\subsection{Empirical model}

In order to investigate the determinants of the duration of the appeals process, we estimate the following OLS model:

$$
\text { Dur_decision }=\beta_{0}+\beta_{1}^{\prime} \text { Authority }+\beta_{2}^{\prime} \text { Court }+\beta_{3}^{\prime} \text { Appeals }+\beta_{4}^{\prime} \text { Fine }+\beta_{5}^{\prime} \text { Group }+u
$$

The dependent variable Dur_decision equals the overall duration (in months) needed by the two courts to decide the respective case. The independent variables included into our model refer to the five sets of variables identified in Section 3 above as potential drivers of the duration of the appeals process: authority-related (Authority), court-related (Court), appealsrelated (Appeal), fine-related (Fine) and group-related (Group). The error term is denoted by $u$. 
In order to take account of the institutional details of the appeals process in the European Union with the first-stage appellate court investigating the substance of the case and the second-stage appellate court only deciding on the correct application of the law, we will estimate the described model, in a first step, by applying it to the entire data set and therefore both stages of the appeals process. In a second step, we will run the same estimations separately for the two stages. In these estimations, the dependent variables are then given by the duration of the appeals processes on the two separate stages. Introducing such a differentiation will allow us to test whether the two stages structurally differ in terms of drivers of the duration of the respective proceedings.

\subsection{Construction of the data set and descriptive statistics}

The raw data set used in this article contains information on all cartel cases and appeals decisions decided by the European Commission (EC), the General Court (GC) of the European Union and the European Court of Justice (ECJ) between 2000 and 2012. The data were collected from decisions and press releases published by the EC in the course of its investigations as well as from judgment documents provided by the online platform CVRIA. ${ }^{17}$ The data set combines case-specific, firm group-specific and firm-specific information. Firm groups were formed according to the respective EC decisions, i.e., firms within one group are linked through ownership and are jointly liable for cartel fines. For our empirical analysis we use data on the group level rather than on the firm level because most variables do not differ substantially between single firms within a certain group. ${ }^{18}$ Using firm level data would therefore result in an unjustified multiplication of the sample size without providing any additional information. The data set is restricted to firm groups that decided to challenge the respective EC decisions and for which the final court decision was already available. ${ }^{19}$ In total, the data set combines information on 234 firm-groups from 63 cartel cases. ${ }^{20}$ Table 1

17 See http://curia.europa.eu for further information.

18 In some cases, several firms within the same firm group decided to file separate appeals with the GC/ECJ. In those cases, aggregate variables on the group level were created, i.e., the duration of the appeals process for the entire group is given by the average duration of the separate appeals.

19 Appeals that were still pending at the time of the finalization of the data set (in February 2014) were excluded entirely from the empirical analysis in order to avoid biases.

20 It is worth noting that - for our empirical analysis - we divided some of the decided EC cartel cases into several separate cases, basically because some EC decisions cover several distinct cases within one judgment (e.g., as they either refer to similar product markets or the same product market in different geographical regions). The creation of such distinct cases is important in order to aggregate our group-related variables appropriately. The number of cartel cases included in our empirical analysis is 54 according to the EC statistics (rather than 63 according to our classification). 
summarizes descriptive statistics of the collected variables. A detailed list of variables is provided in Table 3 in the Annex.

Table 1: Descriptive statistics

\begin{tabular}{|c|c|c|c|c|c|}
\hline Variable & Mean & Std. dev. & Min & Max & Obs \\
\hline \multicolumn{6}{|c|}{ Authority-related variables } \\
\hline Dur_investigation & 52.2051 & 21.0254 & 7 & 114 & 234 \\
\hline Dur_detection & 0.9359 & 16.0701 & -39 & 51 & 234 \\
\hline Fine_guideline_06 & 0.1709 & 0.3773 & 0 & 1 & 234 \\
\hline \multicolumn{6}{|l|}{ Court-related variables } \\
\hline Dur_decision & 56.3889 & 16.6699 & 5 & 102 & 234 \\
\hline Dur_decision_GC & 48.8752 & 13.7932 & 5 & 81 & 234 \\
\hline Dur_decision_ECJ & 15.8238 & 11.6097 & 0 & 56 & 96 \\
\hline No_appeals_12m_GC & 30.5513 & 18.6918 & 1 & 72 & 234 \\
\hline No_appeals_12m_ECJ & 17.6146 & 13.5136 & 0 & 51 & 234 \\
\hline \multicolumn{6}{|l|}{ Appeals-related variables } \\
\hline Twostages_ec & 0.1068 & 0.3096 & 0 & 1 & 234 \\
\hline Twostages_firmgroup & 0.4103 & 0.4929 & 0 & 1 & 234 \\
\hline Appeal_success & 0.4658 & 0.4999 & 0 & 1 & 234 \\
\hline No_pleas & 5.5996 & 3.1945 & 1 & 20 & 234 \\
\hline Fine_annulment & 0.9231 & 0.2670 & 0 & 1 & 234 \\
\hline \multicolumn{6}{|l|}{ Fine-related variables } \\
\hline Leniency_reduction & 0.1278 & 0.1681 & 0 & 1 & 234 \\
\hline Aggrav_circum & 0.2308 & 0.4222 & 0 & 1 & 234 \\
\hline Mitig_circum & 0.2265 & 0.4195 & 0 & 1 & 234 \\
\hline \multicolumn{6}{|l|}{ Group-related variables } \\
\hline No_countries & 1.4829 & 0.9548 & 1 & 8 & 234 \\
\hline No_firms & 1.9316 & 1.4515 & 1 & 12 & 234 \\
\hline
\end{tabular}

Although it appears dispensable to provide a detailed discussion of the descriptive statistics of all variables shown in Table 1, we would like to point to a few key insights. First, it is shown that the duration of an investigation by the European Commission lasts on average about 52 months with a spectrum from 7 months to 114 months. ${ }^{21}$ Second, interestingly, the duration of the entire appeals process is similar with an average duration of 56 months and minimum and maximum values of 5 months and 102 months, respectively. However, the split between a first- and a second-stage appeals process reveals that the latter (about 16 months) is substantially shorter than the former (about 49 months) reflecting the differences in their aims and scopes discussed in Section 2.3 above. Third, Table 1 reveals that there is substantial variation in the number of appeals submitted to the GC (ECJ) within 12 months before a

21 Please note that the value of -39 months as minimum value for the Dur_detection variable is explained by a case in which the cartel continued to operate after the EC started an investigation. 
certain appeal. On average, the GC (ECJ) has to handle 30 (18) separate cases with 1 (0) and 72 (51) delineating the spectrum.

\subsection{Estimation results}

In this section, we present the key results of our empirical analysis. We follow the structure of the derivation of our hypotheses in Section 3 and differentiate between five sets of explanatory variables: authority-related, court-related, appeals-related, fine-related and grouprelated. Within these groups of variables, we will discuss the implications of the results of all three regression results shown in Table 2: both appeals stages together and separate estimates for stage 1 (General Court of the European Union) and stage 2 (European Court of Justice).

Starting off with the authority-related determinants, Table 2 above reveals that only the duration of first-stage appellate proceedings is increasing with an enlarging time span between cartel breakdown and beginning of the EC investigation thereby confirming our hypothesis developed above. While the duration of the EC investigation is found to have no significant impact on the duration of either first- or second-stage appellate court proceedings, the implementation of the EC Guidelines on the Method of Setting Fines in 2006 had a substantial effect: the average duration of a first-stage court investigation decreases by about 12 months in first-stage appellate court proceedings and 11 months in second-stage appellate court proceedings.

Turning to the court-related determinants, we find that the number of appeals submitted within 12 months before an appeal has a highly significant impact on the duration of firststage appellate court decisions. The more cases are handled by the GC in parallel, the longer the average duration of the proceedings. Interestingly, a corresponding effect cannot be found for second-stage appellate court decisions.

The appeals-related determinants of the duration of appellate court proceedings also reveal diverging results for the first and the second stage. While the estimation of both stages reveal that a second-stage court proceeding increases the duration of the entire appeals process by about 11 months when the EC has initiated the appeal and about 17 months in cases in which the firms appealed, the separate regressions of the two stages reveal that only the fine annulment variable shows a significantly negative effect on the duration of first-stage appellate proceedings. Interestingly, the number of pleas filed by the parties does not significantly influence the duration of appeals proceedings. Likewise, successful appeals show no significant difference in investigation length compared to unsuccessful appeals, suggesting that the appeals are treated equally by the courts irrespective of the outcome. 
Table 2: Estimation results

\begin{tabular}{|c|c|c|c|c|c|c|}
\hline Authority-related variable & \multicolumn{2}{|c|}{$\begin{array}{l}\text { Both stages } \\
\text { (GC and ECJ) }\end{array}$} & \multicolumn{2}{|c|}{ Stage 1: GC } & \multicolumn{2}{|c|}{ Stage 2: ECJ } \\
\hline Dur_investigation & -0.0671 & $(-1.64)$ & -0.0376 & $(-1.01)$ & -0.0927 & $(-1.27)$ \\
\hline Dur_detection & $0.191^{* * *}$ & $(3.51)$ & $0.210^{* * *}$ & $(4.70)$ & 0.0179 & $(0.19)$ \\
\hline Fine_guideline_06 & $-19.55^{* * *}$ & $(-7.80)$ & $-12.36^{* * *}$ & $(-5.37)$ & $-10.57^{* * *}$ & $(-2.64)$ \\
\hline \multicolumn{7}{|l|}{ Court-related variable } \\
\hline No_appeals_12m & $0.196^{* * *}$ & $(3.73)$ & $0.188^{* * *}$ & $(4.05)$ & -0.0878 & $(-0.93)$ \\
\hline \multicolumn{7}{|l|}{ Appeals-related variables } \\
\hline Twostages_ec & $11.33^{* * *}$ & $(4.24)$ & & & & \\
\hline Twostages_firmgroup & $16.58^{* * *}$ & (8.59) & & & & \\
\hline Appeal_success & -1.352 & $(-0.69)$ & -2.158 & $(-1.08)$ & 3.668 & $(1.28)$ \\
\hline No_pleas & -0.279 & $(-0.95)$ & -0.332 & $(-1.19)$ & 0.182 & $(0.54)$ \\
\hline Fine_annulment & $-12.72^{* * *}$ & $(-4.10)$ & $-11.76^{* * *}$ & $(-3.98)$ & -4.210 & $(-1.29)$ \\
\hline \multicolumn{7}{|l|}{ Fine-related variables } \\
\hline Leniency_reduction & $-11.03^{*}$ & $(-1.94)$ & $-10.09^{*}$ & $(-1.80)$ & -4.591 & $(-0.66)$ \\
\hline Aggrav_circum & -0.954 & $(-0.39)$ & -0.235 & $(-0.09)$ & -1.082 & $(-0.35)$ \\
\hline Mitig_circum & $-4.515^{*}$ & $(-1.74)$ & -3.068 & $(-1.21)$ & $-5.991^{*}$ & $(-1.71)$ \\
\hline \multicolumn{7}{|l|}{ Group-related variables } \\
\hline No_countries & 1.059 & $(0.55)$ & 1.389 & $(0.64)$ & -0.200 & $(-0.11)$ \\
\hline No_firms & -1.106 & $(-0.74)$ & -0.502 & $(-0.30)$ & -1.012 & $(-0.71)$ \\
\hline Cons & $66.21^{* * *}$ & $(15.71)$ & $61.69^{* * *}$ & $(16.00)$ & $30.11^{* * *}$ & $(4.95)$ \\
\hline$N$ & \multicolumn{2}{|c|}{234} & \multicolumn{2}{|c|}{234} & \multicolumn{2}{|c|}{96} \\
\hline$R^{2}$ & \multicolumn{2}{|c|}{0.502} & \multicolumn{2}{|c|}{0.295} & \multicolumn{2}{|c|}{0.296} \\
\hline adj. $R^{2}$ & \multicolumn{2}{|c|}{0.471} & \multicolumn{2}{|c|}{0.257} & \multicolumn{2}{|c|}{0.194} \\
\hline
\end{tabular}


Turning to the fine-related determinants, we find that the higher the level of percentage reduction of the basic amount of the fine due to a leniency application - a measure of the degree of cooperation of the group with the Commission - the higher the reduction in the duration of first-stage appellate court proceedings thereby confirming our hypothesis derived in Section 3 above. Interestingly, the presence of mitigating factors only lead to a reduction in the duration of second-stage appellate court proceedings while it has no significant effect in first-stage proceedings.

Last but not least, the results for the group-related determinants of the duration of appellate court proceedings have to be discussed. As revealed by Table 2, neither the number of countries nor the number of firms has a significant effect on the duration of either first- or second-stage appellate court proceedings.

In sum, our empirical results reveal that the speed of a first-stage appellate court decision depends on the court's appeals-related workload, the complexity of the case, the degree of cooperation by the firms involved and the clarity of applied rules and regulations. Interestingly, second-stage appellate court decision appears to be largely unaffected by those drivers and only show a significant reduction in the duration after the implementation of the EC Guidelines on the Method of Setting Fines in 2006 and the existence of mitigating factors in the calculation of the final fine. While on the surface, this finding appears to be surprising, the above description of the appeals process with the first-stage appellate court investigating the substance of the case and the second-stage appellate court only investigating the correct application of the law provides more than an explanation why the (substantially different) average durations of the two stages are found to be affected by largely different drivers.

\subsection{Implications for firms and public policy makers}

Based on the description of our empirical results in the preceding section, we will now turn to a discussion of their implications for both firms that plan to file an appeal as well as public policy makers. Assuming that a firm as rational decision maker decides to file an appeal if the net present value of the investment can be expected to be positive, the question is posed how our empirical results help in conducting such an assessment. Ceteris paribus, our results, first, suggest that special types of (more complex older) cases can be expected to cause a substantially longer investigation length thereby reducing the net present value of the respective investment in the appeals process. The same conclusion is true in a situation in which a certain case is added to an already high workload of the GC thereby triggering longer investigation lengths and consequently higher costs for the respective firm. However, if the 
firm participated in the leniency program of the EC, it can expect to have a significantly shorter investigation length thereby increasing the incentives to file an appeal.

Although on the surface, it appears straightforward to assume that firms have an interest in short appeals processes for the cost-related reasons discussed in Section 2 above, the rising importance of private antitrust enforcement in Europe questions this assumption. Due to the fact that cartel damage claims in Europe are typically filed as follow-on cases, the appeals process factually delays the beginning of such trials and therefore provides an incentive for former cartel members to (frivolously) extend the length of the appeals process (or even to initiate one in the first place).

Turning to the implications of our results for public policy makers, they, first, suggest that the provision of clear rules and regulations has a strong positive effect on procedural efficiency reflected in substantially shorter investigation lengths. In particular, the implementation of the EC Guidelines on the Method of Setting Fines in 2006 is found to have such an effect suggesting that further clarifications of administrative procedures have the potential to reduce the duration of proceedings further.

Second, our results suggest that specific forms of cooperation between the authority or court and the respective firms have the potential to increase procedural efficiency through quicker judgments. In particular, the introduction of the leniency program and therewith the possibility for firms to receive fine reductions in exchange for full cooperation with the authority led to a substantial reduction in the duration of first-stage appellate court proceedings suggesting that increases in the attractiveness of the leniency program design or its implementation are likely to further promote the speed of appellate court proceedings (at the cost of a decreased deterrence effect of anti-cartel law enforcement).

Third, our results also confirm the expectation that the capacity and capacity utilization of the first-stage appellate court system is a key determinant of procedural efficiency. The more cases the court has to review, the longer the respective duration of the proceedings suggesting that policy makers have the possibility to improve investigation speed by simply increasing the number of judges (or other bottleneck resources) in the court system. However, incremental costs and benefits of such a step need to be compared to assure that net social welfare is actually likely to be increased. Such an assessment would have to include the effects of a higher/lower number of judges on qualitative aspects of the proceedings and decisions, i.e., first and foremost the probability and severity of legal errors. ${ }^{22}$

22 For example, hiring additional judges would likely not only affect the quantity side but also the quality side, e.g., because a larger number of judges would allow a higher degree of specialization thereby promoting the 


\section{Conclusion}

It is undisputed that an efficient court system is not only an important cornerstone in the creation and maintenance of a workable and sustainable judicial system but also of tremendous importance in attaining the more general aim of a solid implementation of a constitutional order. Although admittedly subject to several simplifying assumptions, an efficient court system can be thought of maximizing the net social benefit by making an optimal number of correct decisions with the lowest possible use of resources. For example, a court that (regularly) reaches correct decisions in three months would be considered more efficient than a court that comes to the same correct decisions after four months.

Although it is obvious that - in complex cases - the duration of the proceeding may be correlated with the accuracy and correctness of the decision, i.e., longer decision making processes (e.g., due to a cautious review of all pieces of evidence) may reduce the likelihood of erroneous decisions, it also cannot be ignored that the duration of a court investigation is of great importance for both firms and society. For example, if any appeals decision would take a prohibitively long time span, say twenty years, firms would refrain from appealing due to, e.g., the substantial amount of labor costs accrued and - as a consequence - the constitutional order would be at risk as firms are taken the factual possibility to defend themselves against (possibly arbitrary) decisions by public authorities or courts.

Against this background, we use data of 234 firm groups that participated in 63 cartels convicted by the European Commission between 2000 and 2012 to investigate the determinants of the duration of the subsequent one- or two-stage appeals process. We find that while the speed of the first-stage appellate court decision depends on the court's appealsrelated workload, the complexity of the case, the degree of cooperation by the firms involved and the clarity of the applied rules and regulations, the second-stage appellate court proceedings appear to be largely unaffected by those drivers. Our empirical results do not only provide valuable insights for firms in their decision to file an appeal - as the duration of the appellate court proceedings must be considered as a major cost driver - but especially point to several parameters policy makers can vary if they believe that it is in the public interest to either increase or decrease the speed of appellate court proceedings. Examples include changes in the capacity and/or degree of specialization of the appellate courts, the clarity of rules and regulations (such as fine guidelines) or the provision of incentives for former cartel members to support the public authority (and subsequently the court(s)) in a 
complete assessment of both the existence and the scope of the cartel agreement at hand (e.g., through a leniency program).

Our empirical results together with a few identified shortcomings suggest several avenues for future research. One interesting area in this respect is field studies in appellate courts to learn more on the real bottlenecks in their everyday investigation work. Such studies are likely to allow the inclusion of further variables (possibly) reaching an even better explanatory value of an empirical analysis. Another fruitful area of future research is international comparisons of investigation lengths and their determinants. Although it is obvious that legislative (and related) differences across countries will complicate such an endeavor, benchmarking exercises would still enable efficiency comparisons and would therefore allow basing policy conclusions on more robust foundations. A third and last promising area of future research is to complement our efficiency measure of an appellate court system - the duration of the appeals process - with richer measures that explicitly take the relationship between investigation length and the likelihood (and severity) of errors (i.e., the quality of the respective decisions) into account. In this respect, it would also be important to learn more on the motivations of firms to file an appeal. The range of possible reasons reaches from the true belief that the decision of the Commission was wrong via an attempt to receive some degree of fine reduction up to the filing of frivolous appeals that, e.g., aim at delaying (follow-on) private enforcement activities of customers harmed by the typically elevated prices set by the former cartel members.

\section{References}

Baye, M.R. and Wright, J.D. (2011), Is Antitrust Too Complicated for Generalist Judges? The Impact of Economic Complexity and Judicial Training on Appeals, Journal of Law and Economics 54 (1), 1-24.

Camesasca, P., J. Ysewyn, T. Weck, and B. Bowman (2013), Cartel Appeals to the Court of Justice: The Song of the Sirens?, Journal of European Competition Law \& Practice 4 (3), 215-223.

Carree, M., A. Günster and M. Schinkel (2010), European Antitrust Policy 1957-2004: An Analysis of Commission Decisions, Review of Industrial Organization 36, 97-131.

Chopard, B., E. Marion and L. Roussey (2014), Appeals Process, Judicial Errors and Crime Deterrence, Working Paper, University of Paris Ouest, Nanterre.

Clermont, K. and T. Eisenberg (2001), Appeal from Jury or Judge Trial: Defendants' Advantage, American Law and Economics Review 3 (1), 125-164. 
Cooter, R. and T. Ulen (2000), Law and Economics, Third Edition, Addison-Wesley, Reading.

Daughety, A. and J. Reinganum (2000), Appealing Judgments, RAND Journal of Economics 31 (3), 502-525.

Eisenberg, T. and H. Farber (2013), Why Do Plaintiffs Lose Appeals? Biased Trial Courts, Litigious Losers, or Low Trial Win Rates?, American Law and Economics Review 15 (1), 73-109.

Geradin, D. and D. Henry (2005), The EC Fining Policy for Violations of Competition Law: An Empirical Review of the Commission Decisional Practice and the Community Courts' Judgments, European Competition Journal 1 (2), 401-473.

Günster, A., M. Carree and M. Schinkel (2010), A Statistical Analysis of Court of Appeals Rulings in European Antitrust Enforcement, 1957-2004, Working Paper, University of Maastricht.

Harding, C. and A. Gibbs (2005), Why Go to Court in Europe? An Analysis of Cartel Appeals 1995-2004, European Law Review 30 (3), 349-362.

Hüschelrath, K., U. Laitenberger and F. Smuda (2013), Cartel Enforcement in the European Union: Determinants of the Duration of Investigations, European Competition Law Review 34 (1), 33-39.

Levy, G. (2005), Careerist Judges and the Appeals Process, RAND Journal of Economics 36 (2), 275-297.

Martineau, R. (1984), Frivolous Appeals: The Uncertain Federal Response, Duke Law Journal 1984 (5), 845-886.

Miceli, T. (2009), The Economic Approach to Law, Stanford University Press, Stanford.

Nobles, R. and D. Schiff (2002), The Right to Appeal and Workable Systems of Justice, Modern Law Review 65 (5), 676-701.

Ormosi, P., (2012), Tactical Dilatory Practice in Litigation: Evidence from EC Merger Proceedings, International Review of Law and Economics 32 (4), 370-377.

Santolino, M. (2010), Determinants of the Decision to Appeal Against Motor Bodily Injury Judgements Made by Spanish Trial Courts, International Review of Law and Economics 30 (1), 37-45.

Schweitzer, H. (2013), Judicial Review in EU Competition Law, in: Lianos, I. and D. Geradin, Handbook on European Competition Law - Enforcement and Procedure, Edward Elgar, Cheltenham. 
Shavell, S. (1995), The Appeals Process as a Means of Error Correction, Journal of Legal Studies 24 (2), 379-426.

Shavell, S. (2006), The Appeals Process and Adjudicator Incentives, Journal of Legal Studies 35 (1), 1-29.

Shavell, S. (2010), On the Design of the Appeals Process: The Optimal Use of Discretionary Review versus Direct Appeal, Journal of Legal Studies 39 (1), 63-107. 


\section{Annex}

Table 3: List of variables

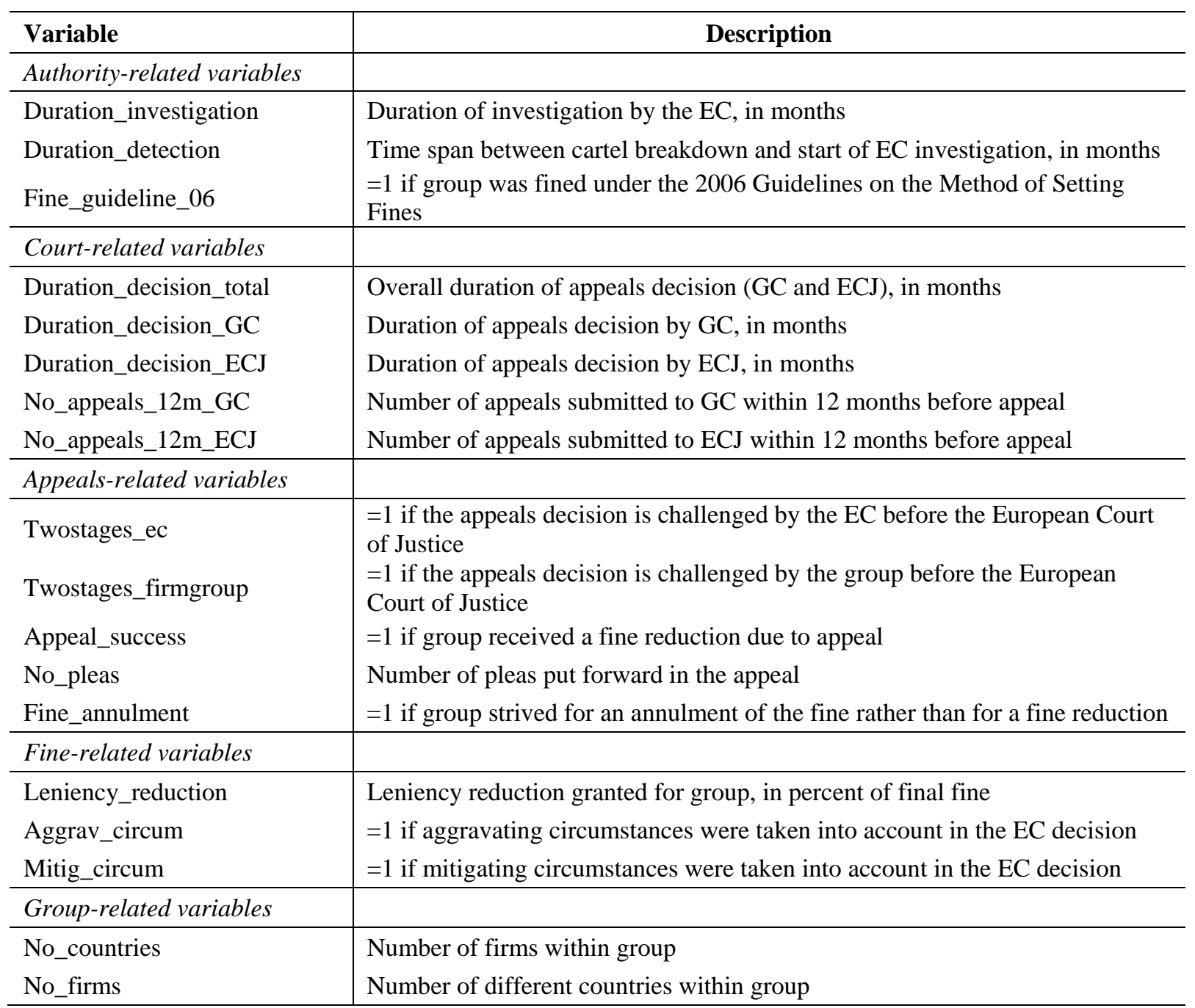

